\title{
Water Schedule of Roselle (Hibiscus sabdariffa L.) Under Organic Fertilization
}

\author{
M. Hewidy*, Engy Sultan ${ }^{* *}$ and Maha Elsayed** \\ *Horticulture department, Faculty of Agriculture, Ain Shams University, Cairo, Egypt \\ ${ }^{* *}$ Central Laboratory for Agricultural Climate, Agricultural Research Centre, Cairo, \\ Egypt.
}

\begin{abstract}
$\mathbf{H}^{\prime}$ IBISCUS sabdariffa L. (Roselle) isaherbal medicineplant that has severaluses, i.e. as a food or a flavouring agent in the food industry, and also in hot and cold beverages. It is a cash crop in arid and semi-arid zones. The experiment was conducted to study the effect of irrigation and compost applicationon Roselle in Rasheed, Egypt. Water supplyfrequency was divided into three different timingsin 2, 4 and 6 days intervals. In addition to mineral fertilizers, soil media were supported with compost as a soil amendment at 5, 10 and $15 \mathrm{t} \mathrm{fed}^{-1}$.

The positive effect of irrigation and compost application was monitored on plant height, stem diameter, number of leaves, branches and fruits, dry weight of plantand calyx. Leaf chlorophyll contents and calyx anthocyanin composition were positively increased with the increase in interval and compost application.
\end{abstract}

Keywords: Roselle, Hibiscus sabdariffa, Irrigation, Compost, Anthocyanin, Calyx, Medicinal plant.

\section{Introduction}

Hibiscussabdariffa is commonly known under the common names of Roselle, hibiscus, Jamaica sorrel or red sorrel and 'karkadeh'. Roselle is a summer annual crop that can reach up to $2.4 \mathrm{~min}$ length.Leaves are alternate situated on cylindrical red stems. Roselle is a perfect multifunctionmodel for food, feed, fiber and medicine (Dutt et al., 2009) andit grows productively in the tropics and sub-tropics (Begum et al., 2015). The young or tender leaves are consumed as a green vegetable andthe main product of this crop is the calyx and epicalyx that is utilized in preparation of beverages (Ottai et al., 2006). Also, Lin et al. (2007) has disclosed benefits of Roselle extract that acts as sexual stimulator, appetizer, cathartic, cancer-protective, anti-cough and refrigerant. H. sabdariffa foremost relevant constituents are organic acids, anthocyanins, polysaccharides and flavonoids (Müller and Franz, 1992). Final fruit production of a single plant can extend to about $1.5 \mathrm{~kg}$, approximately 8 tha $^{-1}$. Roselle leaves yield may amount to10 tha ${ }^{-1}$ (EcoCrop, 2007). DaCosta-Rocha et al (2014) reviewedthe importance of Roselle extract and showed it to include antibacterial, anti-oxidant, nephro- and hepato- protective renal/diuretic effect, anti-cholesterol, anti-diabetic and anti-hypertensive effects among others. This might be associated with strong antioxidant activities, repression of $\alpha$-glucosidase and $\alpha$-amylase, inhibition of angiotensinconverting enzymes (ACE), and direct vasorelaxant effect or calcium channel modulation. Phenolic acids (esp. protocatechuic acid), organic acid hydroxycitric acid, hibiscus acid and anthocyanins (delphinidin-3-sambubioside and cyanidin-3-sambubioside) are conducive to the reported effects. However, its slow growth at the initial stage leading to increase of weeding cost and land occupation (Wilson andMenzel, 1964) which normally engages the land for $6-8$ months a year.

The plant can grow readily in well-drained soils and can tolerate poor soils, high temperature and drought. It requires 4-8 months with minimum night-time temperature $20^{\circ} \mathrm{C}, 13 \mathrm{~h}$ of sunlight and monthly rainfall $130-150 \mathrm{~mm}$ to avert premature flowering. There are many signsto suggest native existence in Saudi Arabia, Sudan, China, India and Malysia. Cultivation of the crop has been revealed throughout India, part of Asia, America, Australia and throughout Africa (Cobley, 1976). 
This may explain why Roselle cultivation is mainly accustomed to grow in upper Egypt (ElBoraie et al., 2009). The first country certified for organic production of Roselle was Egypt. Lately, a number of producers have been accredited by the fair-trade labelingsystem (Brinckmann, 2011). In some countries, importing Egyptian Roselle requiresa fair trade certificate to prove originality of the product. Well-knowingly, organic farming increases value of different products in agriculture and food trade (Bavec and Bavec, 2007).

Water is the main element of life.Efficient irrigation is a must in arid regions and by the looks of it is an obstacle in the improvement of crop production in the world (Yang et al., 2006). Proper management is essential in order to save water and maximize the benefits of water consumption. Roselle exhibited low water demand and the plant kept growing even at irrigation treatment of $20 \%$ ETo (Seghatoleslami et al., 2013).A long wide literature on water supply is available, most of researchers were focused onwater stress effect on biomass, yield and active constituents of different medicinal and aromatic plants. However in a lot of cases, they stated an increase in flowering and dry yield. Seghatoleslami et al. (2013) found that water supply level had nosignificant effects on Roselle plant height, stem diameter, number of branchesand on stomatal closure.Also they found that irrigation treatment was only connected with chlorophyll contents in leaves.Drought stress or overwatering exhibited a decrease in flower number, fresh weight and dry weight (El-Boraie et al., 2009). In addition, the same authorsannounced an increment in anthocyanin subsequent to the increase of water supply and added that stress condition is an elevator for carbohydrate accumulation that amassed into anthocyanin and other secondary metabolites.In another research, water schedule under light soil cultivations did not affect Roselle plant height and branches number but instead number of leaves and calyx yield significantly increased under longer intervals only (Babatunde and Mofoke, 2006). Longer water supply interval articulates a level of stress on plants even though equal amount of water were supplied with shorter intervals. However, water stress led to reductions in plant height, calyx yield and quality of Roselle (Khalil and Yousef, 2014). In heavy soil lands, water supply depends mainly on flooding irrigation. Increase water supply or reduction of water intervals were connected with a surge increase in the final yield of Roselle calyx (Mandour et al.,
1979). They found also that increasing intervals between irrigation gave a significant increase in the total soluble solids in Roselle beverage.

Continuous increase in fertilizer application causes lowering soil health. Synthetic fertilizershigh cost deters most farmers fromsupplying a balanced application of nutrients which leads to low productivity. Organic fertilization is considered the most competent adaptation method for slow growing crops. Bekeko (2014) defined adequate fertilization programs as the amount of plant nutrients that can support maximum net returns. Plant nutrients provided by compost are not enough for growing sof plants that force growers to use some additives (Eklind et al., 1998). Increase mineral fertilization application rates were attributed with elongating the juvenile stage in variouscrops, thus hold back crop maturity (Udoh, 2005). While, organic fertilization has been reported to promote vegetative growth in plants.In confirmation, Oyewole and Mera (2010) reported similar tendency in extension of juvenile stage and delay of flowering with mineral fertilization. Positive effects for organic fertilization has been cited on Rosellecalyx dry weight (Oyewole and Mera, 2010, Mahran et al., 1978). In fact, Roselle needs very low amount of nutrient 40:20:20 units of N:P:K (Saha et al., 2008). Low fertilization rate causes earliness in flowering followed by a reduction in the final yield (Oyewole and Mera, 2010). Organic fertilizer plays an important role in balancing plant nutrition by improving physical, chemical and biological properties of soil. It contains most of known trace minerals essential to the development of plant's life.Heavy use of chemical fertilizer is not recommended in Roselle cultivation due to slow growing rate and long growing period. Furthermore, mineral fertilization residue has brought about a variety of economic, environmental and social problems (Mohan, 1989), since overuse of chemical fertilizers and pesticides had effects on the soil organisms that are exactly the same as to human overuse of antibiotics.

This study was aimed to evaluate the effect of irrigation schedule and compost application on growth and yieldquantity and quality of Hibiscus sabdariffa L. grown in a loam soil.

\section{Material and Methods}

Cultivation of Roselle was carried outin two successive seasons 2014 and 2015 at El- 
BosailyResearch Station, Agriculture Research Center at Rasheed, Egypt(latitude of $31^{\circ} 27^{\prime} 15^{\prime \prime}$ $\mathrm{N}$, longitude $30^{\circ} 23^{\prime} 23^{\prime}$ 'E). The physical and chemical characteristics of the soil experiment field were determined according to Jackson (1973) and are shown in Table 1.

This experiment was designed using a factorial split - plot design, the main plots were assigned to irrigation intervals every 2, 4 or 6 days. While, the subplots were assigned to compost at the rates of $0,5,10$ and $15 \mathrm{t} \mathrm{fed}^{-1}$.

\section{Experimental procedures}

\section{Soil preparation}

The soil was prepared before sowing by adding compostat the rates of $0,5,10$ and $15 \mathrm{t}$ $\mathrm{fed}^{-1}$. Compost originated from organic green wastes collected from farmyard of El-Bosaily experimental farm at Rashid, Egypt. Nonfertilizedcontrol plotsreceived the recommended units of NPK 25:25:25per fedan. Irrigation of different fertilization rates was done in schedule of each 2, 4 or 6 days. The experiment was conducted in a completely randomized design.

\section{Plant material}

Seed were directly sowed in prepared plots in the experimental field on $1^{\text {st }}$ and $5^{\text {th }}$ of March to $15^{\text {th }}$ and $20^{\text {th }}$ of November of 2014 and 2015 respectively. After germination the seedlings were thinned leaving one plant/ hill. The seedlings were irrigated when needed until they completely established.

\section{Layout of the experiment}

The experiment included 12 treatments, each experimental unit (plot) was $2 \times 1.0 \mathrm{~m}\left(3.0 \mathrm{~m}^{2}\right)$ and divided into 2 rows with $50 \mathrm{~cm}$ apart and 50 $\mathrm{cm}$ between the plant hills. Then, the treatments replicated three times (36 plots), every replicate contained 10 plants.

\section{Data recorded}

Data were recorded on plant growth and yield at mid-November for for plant height, number of lateral shoots, number of leaves per plant, number of fruit/plant, plant fresh and dry weights, fresh weight of fruits and calyx dry weight/plant. Chlorophyll was determined in leaves using SPAD-502, Konica ,Minolta. Vegetative fresh samples were collected and air-dried then dried in an electric oven to estimate dry weight (g/plant). Anthocyanin was estimated cholorometrically as $\mathrm{mg} / \mathrm{g}$ dry weight. To determine anthocyanin, in a $250 \mathrm{ml}$ beaker, $1 \mathrm{~g}$ of the dried ground calyxes was macerated in $30 \mathrm{ml}$ of ethanol $(95 \%)$ and $1.5 \mathrm{~mol} \mathrm{~L}{ }^{-1} \mathrm{HCl}$ mixture ( 85 ethanol: $15 \mathrm{HCl}, \mathrm{v} / \mathrm{v}$ ) for $24 \mathrm{~h}$ at $4^{\circ} \mathrm{C}$. Afterwards, all of the contents were filtered in a $100 \mathrm{ml}$ volumetric flask using a filter paper (Whatman No. 1). The residue on the filter paper was re-extracted two more times and filtered in the $100 \mathrm{ml}$ volumetric flask until the filtered solution became colorless (AbouArab et al., 2011). Anthocyanin in the extract was measured colorimetrically at a $535 \mathrm{~nm}$ wavelength using a spectrophotometer following the method documented by Du and Francis (1973).

\section{Statistical Analysis}

Data of both seasons were tested for normality and then subjected to a general linear model as described by Rutherford (2001). Significance among mean values was determined using Duncan test at 5\% (Duncan, 1955). All statistical analyses were performed using STATGRAPHICS centurion version 15.2.06 (Stat Point, 2005).

TABLE 1. Soil physical and chemical characteristics of El-Bosaily site in 2014.

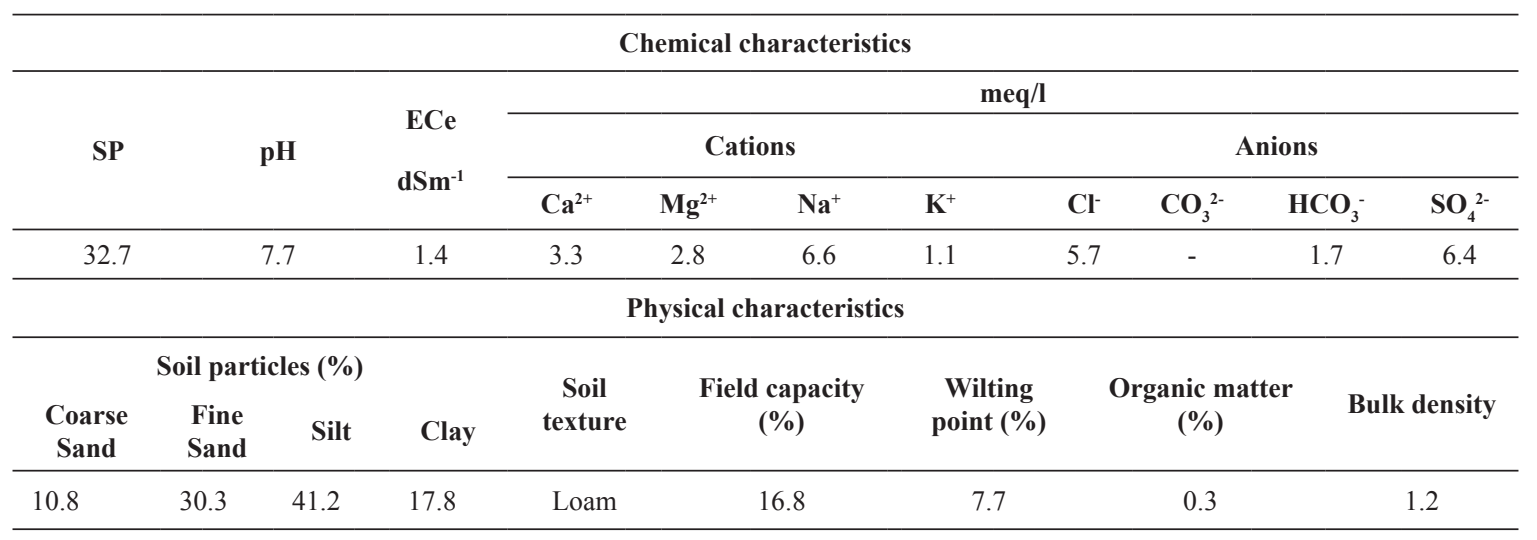




\section{Results}

\section{Plant height}

Plant height was estimated from soil surface to tallest lateral stem (Table 2). Prolonging irrigation interval (every 4 or 6 day) significantly increased plant height as compared with every 2 days. Irrigation interval every 6 days gave the tallest plants in both seasons (182 and $201 \mathrm{~cm}$, respectively). Fertilization rate increment significantly increased plant height. Both fertilization rates of compost at 10 and $15 \mathrm{t} \mathrm{fed}^{-1}$ gave the tallest plants 183 and $187 \mathrm{~cm}$ in $1^{\text {st }}$ season and $(190$ and $202 \mathrm{~cm})$ in the $2^{\text {nd }}$ season, respectively. Six days interval gave taller plants in both seasons with significant differences only in the $2^{\text {nd }}$ season $(201 \mathrm{~cm})$. Among the interaction between compost application and water schedule the tallest plant (200 and $218 \mathrm{~cm}$ ) were observed at $10 \mathrm{t}$ compost and 6 days irrigation interval and (192 and 211) were observed at $15 t$ compost and 4 days irrigation interval in the first and second seasons, respectively.

TABLE 2. Compost application and water schedule effects on plant height, stem diameter and number of branches and leaves, and plant dry biomass of Roselle (Hibiscus sabdariffa) in both cultivation seasons 2014 and 2015.

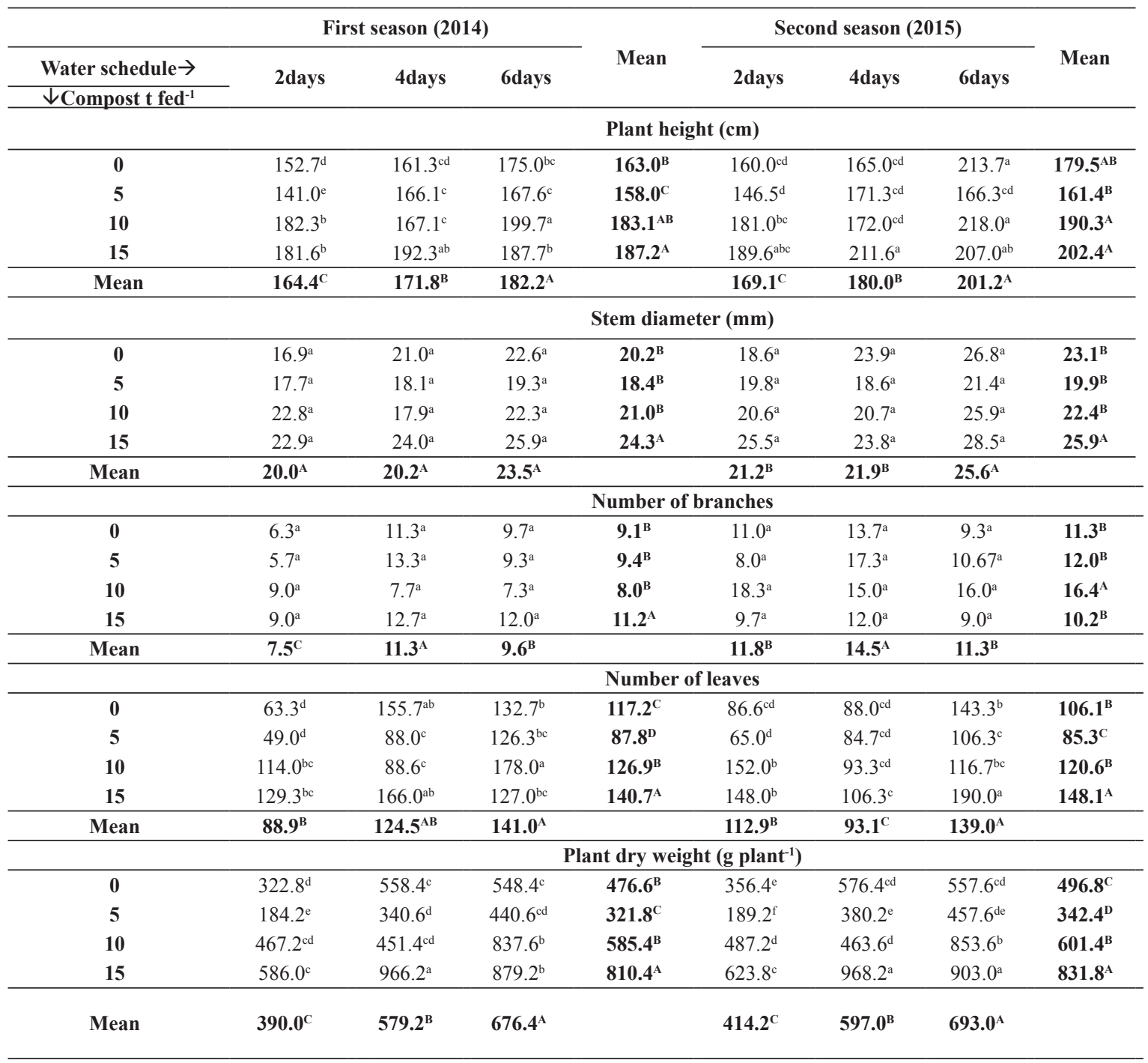

Different letters indicate significant differences between groups $(\mathrm{p}<0.05)$ 


\section{Stem diameter}

Irrigation interval at 6 days showed thickest stem diameter (23 and $26 \mathrm{~mm}$ ) in both seasons, respectively (Table 2). The difference between irrigation intervals every 6 days and other irrigation treatments were statistically significant in the second season. Stem diameter showed significant increases in response to compost application rates. The Highest compost rate of 15 $\mathrm{t} \mathrm{fed}^{-1}$ gave the thickestplants (24 and $26 \mathrm{~mm}$ ) in $1^{\text {st }}$ and $2^{\text {nd }}$ seasons, respectively when compared to other compost rates. Whereas, the differences between compost rates at 5 or $10 \mathrm{tfed}^{-1}$ and control treatments were insignificant in both seasons. As for theeffect of the interaction between compost application rates and irrigation schedule, was notsignificant on stem diameter.

\section{Numberof branches}

Both studied factors showed significant effects on number of branches in both seasons (Table 2). Irrigation interval at 4 days gave the highest branches number 11.3 and 14.5 branches/ plant in both seasons, respectively when compared to other irrigation intervals. Also, compost application at $15 \mathrm{t} \mathrm{fed}^{-1}$ in the first season and at $10 \mathrm{t} \mathrm{fed}^{-1}$ in the second season gave significant increase in number of branches/ plant when compared to other treatments in both seasons. Similarly to stem diameter, the interaction between compost application rates and irrigation schedule showed no significant effect on branches number.

\section{Number of leaves}

Irrigation interval at 6 days gave higher number of leaves (141 and 139) when compared to shorter irrigation interval in the $1^{\text {st }}$ and $2^{\text {nd }}$ seasons, respectively (Table 2). Compost application at $15 \mathrm{t} \mathrm{fed}^{-1}$ gave higher number of leaves (141 and 148) in the $1^{\text {st }}$ and $2^{\text {nd }}$ seasons, respectively when compared to other treatments. As for the interaction, application of 10 or 15 $\mathrm{t}$ fed $^{-1}$ compost at6 days interval gave higher number of leaves (178 and 190)in the $1^{\text {st }}$ and $2^{\text {nd }}$ season, respectivelywhen compared to the other combinations.

\section{Plant dry biomass}

The heaviest plant dry biomass was obtained when plants irrigated every 6 days interval when compared with 2 and 4 days intervals which gave the lowest values in both seasons (Table 2). The heaviest plant dry biomass was obtained when plots were amended with $15 \mathrm{t} \mathrm{fed}^{-1}$ compost compared with compost to other treatments which gave the lowest values in both seasons. Regarding the interaction between compost application and irrigation interval, the heaviest plant dry biomass was obtained when plants were treated with the combination of $15 \mathrm{t} \mathrm{fed}^{-1}$ compost and irrigated every 4 days in both seasons (refer to Table 2 for details).

\section{Number of fruits}

There was a significant effect due to both factors and their interaction on number of fruits (Table 3). Irrigation interval at 6 days gave the highest number of fruits (63 and 87 fruits/plant) in the $1^{\text {st }}$ and $2^{\text {nd }}$ seasons, respectively when compared to shorter irrigation interval.Compost application at $15 \mathrm{t} \mathrm{fed}^{-1}$ gave highest number of fruits (74 and 111 fruits/plant) in the $1^{\text {st }}$ and $2^{\text {nd }}$ season, respectively when compared to other compost rates. As for the interaction, compost application of $15 \mathrm{t} \mathrm{fed}^{-1}$ combined with irrigation interval every 4 and 6 days gave the highest number of fruits 72 and 89 in the $1^{\text {st }}$ season and 106 and 120 in the $2^{\text {nd }}$ season, respectively when compared to the other combinations.

\section{Fresh weight of fruit}

Regarding irrigation intervals, 4 days watering interval gave significant effects on fruit fresh weight (1143 and $\left.1210 \mathrm{~g} \mathrm{plant}^{-1}\right)$, respectively when compared to 2 or 6 days interval in both seasons (Table 3). Application of higher rate of compost $15 \mathrm{t} \mathrm{fed}^{-1}$ gave the highest fruit fresh weight per plant (1419 and $\left.1510 \mathrm{~g} \mathrm{plant}^{-1}\right)$ in $1^{\text {st }}$ and $2^{\text {nd }}$ seasons, respectively. Lower application of compost at $5 \mathrm{t} \mathrm{fed}^{-1}$ showed significant reduction in fruit fresh weight when compared to non-amended plots with compost.As for the interaction, compost application of $15 \mathrm{t} \mathrm{fed}^{-1}$ at different irrigation interval 4 days interval gave higher fruit fresh weight (1683 and 1733 g plant $^{-1}$ ) in the $1^{\text {st }}$ and $2^{\text {nd }}$ seasons, respectively when compared to the other combinations.

\section{Dry weight of calyxes}

The data showed that, 4 days watering interval gave a significant increase on dry weight of calyxes (64.6 and 68.4 gplant $^{-1}$, respectivelyin both seasons) when compared to 2 or 6 days interval (Table 3). Higher application rate of compost $15 \mathrm{t} \mathrm{fed}^{-1}$ gave highest calyxes 80.3 and $85.4 \mathrm{~g}$ dry weight per plant in $1^{\text {st }}$ and $2^{\text {nd }}$ seasons, respectively. Lower application of compost at $5 \mathrm{t}$ fed $^{-1}$ was connected with a significant reduction in calyxes dry weight per plant when compared to non-amended plots with compost. Regarding the interaction, compost at $15 \mathrm{t} \mathrm{fed}^{-1}$ combined with 4 days irrigation interval gave the highest calyxes dry weight (95.2 and $98.0 \mathrm{~g} \mathrm{plant}^{-1}$, respectively in both seasons) when compared to other combinations.

Egypt. J. Hort. Vol. 45, No.1 (2018) 
TABLE 3. Compost application and water schedule effects on fruit number, fruits fresh weight and calyxes dry weight per plant of Roselle (Hibiscus sabdariffa) in both cultivation seasons 2014 and 2015.

\begin{tabular}{|c|c|c|c|c|c|c|c|c|}
\hline \multirow[b]{2}{*}{ 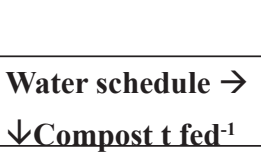 } & \multicolumn{3}{|c|}{ First season (2014) } & \multirow[b]{2}{*}{ Mean } & \multicolumn{3}{|c|}{ Second season (2015) } & \multirow[b]{2}{*}{ Mean } \\
\hline & 2days & 4days & 6days & & 2days & 4days & 6days & \\
\hline & \multicolumn{8}{|c|}{ Numberof fruit } \\
\hline $\mathbf{0}$ & $19.3^{\mathrm{d}}$ & $59.3^{\mathrm{bc}}$ & $54.3^{\mathrm{bc}}$ & $44.3^{\mathrm{BC}}$ & $81.6^{\mathrm{b}}$ & $59.6^{c}$ & $84.6^{\mathrm{b}}$ & $75.3^{\mathrm{B}}$ \\
\hline 5 & $26.3^{\mathrm{d}}$ & $38.0^{\mathrm{c}}$ & $43.0^{\mathrm{c}}$ & $36.7^{\mathrm{C}}$ & $31.7^{\mathrm{d}}$ & $56.6^{\mathrm{c}}$ & $57.0^{\mathrm{c}}$ & $48.4^{\mathrm{C}}$ \\
\hline 10 & $57.3^{\mathrm{b}}$ & $34.0^{\text {cd }}$ & $64.3^{\mathrm{b}}$ & $52.9^{\mathrm{B}}$ & $82.3^{\mathrm{b}}$ & $34.7^{\mathrm{d}}$ & $84.0^{\mathrm{b}}$ & $67.0^{\mathrm{B}}$ \\
\hline 15 & $61.3^{\mathrm{b}}$ & $72.3^{\mathrm{a}}$ & $89.0^{\mathrm{a}}$ & $74.2^{\mathrm{A}}$ & $105.0^{\mathrm{ab}}$ & $106.3^{\mathrm{a}}$ & $120.3^{\mathrm{a}}$ & $110.6^{\mathrm{A}}$ \\
\hline \multirow[t]{2}{*}{ Mean } & $41.0^{C}$ & $51.9^{\mathrm{B}}$ & $62.7^{\mathrm{A}}$ & & $75.1^{\mathrm{B}}$ & $64.3^{\mathrm{C}}$ & $86.5^{\mathrm{A}}$ & \\
\hline & \multicolumn{8}{|c|}{ Fresh weight of fruits $\left(\mathrm{g} \mathrm{plant}^{-1}\right)$} \\
\hline $\mathbf{0}$ & $633.6^{\mathrm{d}}$ & $1188.0^{\mathrm{b}}$ & $792.0^{\mathrm{e}}$ & $871.2^{\text {B }}$ & $644.5^{\mathrm{e}}$ & $1287.0^{\mathrm{c}}$ & $842.5^{\mathrm{d}}$ & $924.0^{B}$ \\
\hline 5 & $653.3^{\mathrm{d}}$ & $911.8^{\mathrm{c}}$ & $796.9^{c}$ & $787.1^{\mathrm{C}}$ & $696.9^{\mathrm{e}}$ & $999.9^{\text {cd }}$ & $806.8^{\mathrm{d}}$ & $834.6^{\mathrm{C}}$ \\
\hline 10 & $871.2^{\text {cd }}$ & $792.0^{c}$ & $594.0^{\mathrm{e}}$ & $752.4^{\mathrm{C}}$ & $881.1^{\mathrm{d}}$ & $821.7^{\mathrm{d}}$ & $603.9^{\mathrm{e}}$ & $768.9^{\mathrm{D}}$ \\
\hline 15 & $1089.0^{\mathrm{b}}$ & $1683.0^{\mathrm{a}}$ & $1485.0^{\mathrm{a}}$ & $1419.0^{A}$ & $1212.7^{\mathrm{c}}$ & $1732.5^{\mathrm{a}}$ & $1584.0^{\mathrm{b}}$ & $1509.8^{A}$ \\
\hline \multirow[t]{2}{*}{ Mean } & $811.8^{\mathrm{C}}$ & $1143.5^{\mathrm{A}}$ & $917.0^{\mathrm{B}}$ & & $858.6^{\mathrm{C}}$ & $1210.2^{\mathrm{A}}$ & $959.0^{\mathrm{B}}$ & \\
\hline & \multicolumn{8}{|c|}{ Dry weight of calyxes $\left(\mathrm{g} \mathrm{plant}^{-1}\right)$} \\
\hline $\mathbf{0}$ & $35.9^{f}$ & $67.2^{\mathrm{c}}$ & $44.8^{\mathrm{e}}$ & $49.3^{\mathrm{B}}$ & $36.4^{\mathrm{e}}$ & $72.8^{c}$ & $47.6^{\mathrm{e}}$ & $52.3^{\mathrm{B}}$ \\
\hline 5 & $36.9^{f}$ & $51.5^{\mathrm{d}}$ & $45.1^{\mathrm{e}}$ & $44.5^{\mathrm{C}}$ & $39.4^{\mathrm{e}}$ & $56.6^{\mathrm{d}}$ & $45.6^{\mathrm{e}}$ & $47.2^{\mathrm{B}}$ \\
\hline 10 & $49.3^{\mathrm{d}}$ & $44.8^{\mathrm{e}}$ & $33.6^{\mathrm{f}}$ & $42.5^{\mathrm{C}}$ & $49.8^{\mathrm{d}}$ & $46.5^{\mathrm{e}}$ & $34.2^{\mathrm{e}}$ & $43.5^{\mathrm{C}}$ \\
\hline 15 & $61.6^{\mathrm{c}}$ & $95.2^{\mathrm{a}}$ & $84.0^{\mathrm{b}}$ & $80.3^{\mathrm{A}}$ & $68.6^{\mathrm{c}}$ & $98.0^{\mathrm{a}}$ & $89.6^{\mathrm{b}}$ & $85.4^{\mathrm{A}}$ \\
\hline Mean & $45.9^{\mathrm{C}}$ & $64.6^{\mathrm{A}}$ & $51.9^{\mathrm{B}}$ & & $48.6^{\mathrm{C}}$ & $68.4^{\mathrm{A}}$ & $54.2^{\mathrm{B}}$ & \\
\hline
\end{tabular}

Different letters indicate significant differences between groups $(\mathrm{p}<0.05)$

\section{Leaf chlorophyll content}

Irrigation every 4 days significantly gave the highest values of chlorophyll content in both seasons compared with other irrigation intervals (Table 4). Also, compost application gave the highest values were obtained when plants received $15 \mathrm{t} \mathrm{fed}^{-1}$ of compost (58 and 59) in the $1^{\text {st }}$ and $2^{\text {nd }}$ seasons, respectively.Regarding the interaction, it was confirmed in both seasons that compost application at $15 \mathrm{t} \mathrm{fed}^{-1}$ in combination with 6 days intervals gave higher leaf chlorophyll content in both seasons.

\section{Anthocyanin content}

The highest calyxes' anthocyanin content was obtained from plants irrigated every 4 days interval compared to irrigation every 2 or 6 days intervals (Table 4). Also, calyxes content of anthocyanin increased significantly when plants were treated with $15 \mathrm{t} \mathrm{fed}^{-1}$ of compost compared to control treatment which gave the lowest anthocyanin contents in both seasons.Concerning the combination between compost application Egypt. J. Hort. Vol. 45, No.1 (2018) and irrigation, the combination between $15 \mathrm{t} \mathrm{fed}^{-1}$ compost and 4 or 6 days interval gave the highest anthocyanin contents in both seasons.

\section{Correlations among different traits}

Qualitative parameters of Roselle, i.e. numberof fruits, dry weight of calyxes and anthocyanin content exhibited significant correlation with some other plant traits (Table 5). Number of fruits was positively correlated with the increase in plant height, stem diameter, number ofleaves, plant dry biomass and chlorophyll content. Also, the increase in dry weight of calyxes was positively correlated with stem diameter, plant dry biomass and chlorophyll content. In addition, anthocyanin content showed relevant significant correlations with plant dry biomass, dry weight of calyxes and chlorophyll content. 
TABLE 4. Compost application and water schedule effects on leaf chlorophyll and calyx anthocyanin content of Roselle (Hibiscus sabdariffa) in both cultivation seasons 2014 and 2015.

\begin{tabular}{|c|c|c|c|c|c|c|c|c|}
\hline \multirow[b]{2}{*}{$\begin{array}{l}\text { Water schedule } \rightarrow \\
\downarrow{\text { Compost } t \text { fed }^{-1}}\end{array}$} & \multicolumn{4}{|c|}{ First season (2014) } & \multicolumn{4}{|c|}{ Second season (2015) } \\
\hline & 2days & 4days & 6days & Mean & 2days & 4days & 6days & Mean \\
\hline & \multicolumn{8}{|c|}{ Chlorophyll contents (SPAD) } \\
\hline $\mathbf{0}$ & $41.4^{\mathrm{d}}$ & $40.2^{\mathrm{d}}$ & $32.8^{\mathrm{e}}$ & $38.1^{\mathrm{C}}$ & $44.6^{\text {de }}$ & $47.1^{\mathrm{cd}}$ & $35.3^{\mathrm{e}}$ & $42.3^{\mathrm{C}}$ \\
\hline 5 & $35.6^{\mathrm{de}}$ & $44.5^{\mathrm{c}}$ & $46.9^{\mathrm{bc}}$ & $42.3^{\mathrm{BC}}$ & $34.7^{\mathrm{e}}$ & $45.2^{\mathrm{d}}$ & $45.8^{\mathrm{d}}$ & $41.6^{\mathrm{C}}$ \\
\hline 10 & $43.2^{c}$ & $51.5^{\mathrm{b}}$ & $45.5^{\mathrm{bc}}$ & $47.7^{\mathrm{B}}$ & $45.7^{\mathrm{d}}$ & $52.5^{\mathrm{c}}$ & $46.7^{\mathrm{cd}}$ & $47.9^{\mathrm{B}}$ \\
\hline 15 & $52.5^{\mathrm{b}}$ & $61.1^{\mathrm{a}}$ & $60.4^{\mathrm{a}}$ & $58.0^{A}$ & $51.5^{\mathrm{c}}$ & $60.4^{\mathrm{b}}$ & $64.4^{\mathrm{a}}$ & $58.7^{\mathrm{A}}$ \\
\hline \multirow[t]{2}{*}{ Mean } & $43.1^{\mathrm{C}}$ & $49.3^{A}$ & $46.5^{\mathrm{B}}$ & & $44.8^{\mathrm{C}}$ & $51.3^{\mathrm{A}}$ & $47.8^{\mathrm{B}}$ & \\
\hline & \multicolumn{8}{|c|}{ Anthocyanin contents (mg g-1 fresh herb) } \\
\hline $\mathbf{0}$ & $11.8^{\mathrm{c}}$ & $11.6^{\mathrm{c}}$ & $9.3^{\mathrm{d}}$ & $10.9^{\mathrm{C}}$ & $13.4^{\mathrm{c}}$ & $11.7^{\mathrm{d}}$ & $10.6^{\mathrm{e}}$ & $11.9^{\mathrm{C}}$ \\
\hline 5 & $10.7^{\mathrm{cd}}$ & $11.6^{\mathrm{c}}$ & $13.1^{\mathrm{ab}}$ & $11.8^{\mathrm{B}}$ & $11.7^{\mathrm{d}}$ & $11.9^{\mathrm{cd}}$ & $13.3^{\mathrm{c}}$ & $12.3^{\mathrm{B}}$ \\
\hline 10 & $9.6^{\mathrm{d}}$ & $13.3^{\mathrm{ab}}$ & $12.5^{\mathrm{b}}$ & $11.8^{\mathrm{B}}$ & $10.0^{\mathrm{e}}$ & $14.2^{\mathrm{b}}$ & $12.9^{c}$ & $12.4^{\mathrm{B}}$ \\
\hline 15 & $13.2^{\mathrm{ab}}$ & $14.0^{\mathrm{a}}$ & $13.3^{\mathrm{ab}}$ & $13.5^{\mathrm{A}}$ & $14.8^{\mathrm{b}}$ & $16.3^{\mathrm{a}}$ & $16.6^{\mathrm{a}}$ & $15.9^{\mathrm{A}}$ \\
\hline Mean & $11.3^{\mathrm{C}}$ & $12.6^{\mathrm{A}}$ & $12.0^{\mathrm{B}}$ & & $12.5^{\mathrm{B}}$ & $13.5^{\mathrm{A}}$ & $13.4^{\mathrm{A}}$ & \\
\hline
\end{tabular}

Different letters indicate significant differences among groups $(\mathrm{p}<0.05)$.

TABLE 5. Correlation among plant traits, chlorophyll and anthocyanin contents ofRoselle (Hibiscus sabdariffa) in both cultivation seasons 2014 and 2015.

\begin{tabular}{|c|c|c|c|c|c|c|c|c|c|c|}
\hline & & \multicolumn{9}{|c|}{ Firstseason (2014) } \\
\hline & & PH & SD & BN & $\mathbf{L N}$ & FN & $\mathbf{C W}$ & PW & TC & ANTH \\
\hline \multirow{9}{*}{ 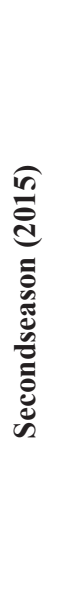 } & PH & & $0.36^{*}$ & 0.28 & $0.59 * * *$ & $0.55 * * *$ & 0.30 & $0.60 * * *$ & $0.39 *$ & 0.22 \\
\hline & SD & $0.45^{* *}$ & & 0.33 & $0.40^{* *}$ & $0.60 * * *$ & $0.46^{* * *}$ & $0.58 * * *$ & $0.34^{*}$ & 0.08 \\
\hline & BN & 0.07 & -0.19 & & 0.26 & 0.27 & $0.45 * *$ & 0.28 & 0.26 & 0.12 \\
\hline & $\mathbf{L N}$ & $0.56^{* * *}$ & $0.49 * * *$ & -0.10 & & $0.78 * * *$ & 0.32 & $0.59 * * *$ & 0.24 & 0.19 \\
\hline & FN & $0.62 * * *$ & $0.50 * * *$ & -0.14 & $0.73 * * *$ & & $0.46^{* *}$ & $0.56 * * *$ & $0.36^{*}$ & 0.17 \\
\hline & $\mathbf{C W}$ & $0.33^{*}$ & $0.33^{*}$ & -0.15 & $0.36^{*}$ & $0.56 * * *$ & & $0.68 * * *$ & $0.73 * * *$ & $0.48^{*}$ \\
\hline & PW & $0.74 * * *$ & $0.54 * * *$ & 0.01 & $0.52 * * *$ & $0.73 * * *$ & $0.66^{* * *}$ & & $0.69 * * *$ & $0.51 * * *$ \\
\hline & TC & $0.36^{*}$ & 0.28 & 0.02 & $0.40^{*}$ & $0.56^{* * *}$ & $0.77 * * *$ & $0.75 * * *$ & & $0.84 * * *$ \\
\hline & ANTH & 0.27 & 0.25 & -0.30 & 0.22 & $0.47 * * *$ & $0.62 * * *$ & $0.61 * * *$ & $0.86^{* * *}$ & \\
\hline
\end{tabular}

PH: plant height, SD: stem diameter, BN: branches number, LN: leaves number, CN: fruit number, CW: calyxesweight, PW: plant biomass, TC: Chlorophyll, ANTH: anthocyanin, *, **, and *** shows statistical significance at the $0.05,0.01$, and 0.001 level, respectively. 


\section{Discussion}

The weather in Egypt is considered to be favorable for most agricultural crops. Various products of medicinal and aromatic plants have great potential in markets. They are used as culinary herbs, or for oil production. Synergy between water supply and organic fertilization occupies interest of both growers and scientistswho try always to reach best combined effect. Level of research on Roselle does not live up to the works done on its closely related species, such as cotton or cannabis (Kumar et al., 1986).

Increase of water stress is trailed by a reduction in growth, yield and fruit quality of Roselle plants (Khalil and Yousef, 2014). Increasing the irrigation interval was correlated with an increase in plant height, stem diameter and leaves number per Roselle plant in both seasons. Similar results were recorded by Hayat (2007), Khalil and Abdel-Kader (2011) and Abbas and Ali (2011) on Roselle plants. However, yield traits of fruit number, fresh and dry weight calyex fresh and dry weight were significantly increased at 4 days interval which reveal a suitable water amendment interval. The short interval between irrigation may not suit a plant like Roselle in light soils and long intervals reduce also yield traits due to adsorbed stress level of water supply delay and frequency. The fact that the correlation between yield and seasonal irrigation water applied for Roselle that diminishes yield return implies that there exists an optimum and then a maximum irrigation level for this crop (Babatunde and Mofoke, 2006). The reductions in plant height under water stress were perhaps due to the drop in cell expansion and culmination more from reduced turgor pressure (Shao et al., 2008). The pronounced effect of increased irrigation water quantity on plant's fresh and dry weights may be attributed to the availability of sufficient moisture around the root thus causing a greater proliferation of root biomass culminating in the higher absorption of nutrients and water leading finally to production of higher vegetative biomass (Singh et al., 1997). Humic acid is one of the degraded organic compounds from compost application that may increase plant resistance to unfavorable conditions, which also improve a process of nitrogen assimilation, but preventing formation of nitrates, and in the meantimesimplifying synthesis of chlorophyll, sugars, vitamins, essential amino-acids, and oils in Capsicum annuum (Khalil et al., 2012). Plants received higher rates of irrigation showed significant increase in total plant fresh and dry weights which was in agreement with that of ElNaggar et al. (2004) on Cyprus papyrus, Moeini et al. (2006) on Ocimumbasilicum, Said-Al Ahl and Abdou (2009) on dragonhead, Said-Al Ahl and Hussein (2010) on oregano and Khalil et al. (2012) on Capsicum annuum L. The synthesis of anthocyanins in the fruitcalyx of Roselle was significantly stimulated by the treatment of 150 $\mathrm{m}^{3}$ irrigation water/irrigation/feddan as well as the 15 days intervally irrigated treatment under heavy soil when they set a comparison among 15, 25, 35 and 45 days intervals. Regulating the irrigation of Hibiscus sabdariffa or growing them under conditions of relative soil moisture stress is more suitable for raising the T.S.S. percentage in their fruit calyxes, a character which is economically advantageous as stated by Mandour et al. (1979).

A fine-tuned fertilization practice is imperative, and forms, rates and times of distribution of fertilizers must be precisely planned and managed (Carrubba, 2015).Use of fertilizer is an indispensable practice to getprime yield. At the meantime, the use of exact types and amounts of fertilizers is prerequisite to aid save threatenedmedicinal and aromatic plants (WHO, 2003). The efficiency of mineral fertilization increase when they are top-dressed when subdivided into 2 or 3 fractions. Whereas, organic fertilization supply dispense nutrients along the growth cycle (Carrubba, 2015). Prasad et al. (2004) demonstrated that actually only $\mathrm{N}$ has a slow release from organic fertilizers, whereas in $\mathrm{P}$ and $\mathrm{K}$ this process evolves rapidly.Very often the slow release of $\mathrm{N}$ from organic fertilizers is alleged to be beneficial with respect to environmental protection (Carrubba, 2015). It is true, however, that in many experiments the $\mathrm{N}$ released from organic fertilizers was not sufficient for economic production, thus eliciting the opportunity to put forward commercial organic fertilizers to a test for $\mathrm{N}$ mineralization ability (Prasad et al., 2004). However, organic fertilization brings a numeral of benefits that elapsethe basic nutritional effect. Yield enhancements from organic fertilization have been tempted for biomass and essential oil in geranium (Araya et al., 2006). Such results might be linked however with soil moisture content, an aspect that was taken into consideration in some experiments on Goji (Lyciumbarbarum L.), where a higher plant dry weight value after organic rather than conventional fertilization was shown in which supplied soil moisture was always kept at optimum level (Chung et al., 
2010). Generally speaking, N fertilizers seem to give the strongest impulse to yield when applied in the faster available forms, and consequently used by the plants since the very first moments after their application. The application of $\mathrm{N}$ in organic form, on the contrary, generates much less evident effects, it is possible that the fertilizer units applied in this form show a delayed effect, since they need to undergo mineralization so as to liberate in the soil mineral nitrogen to be directly used by plants, taking into account that dry conditions do not permit a proper microbiological activity (Chiang et al., 1983). Thus, few authors suggest as best practice the fertilization by means of the recourse to both chemical and organic fertilizers (Joy et al.,1998, Naguib, 2011), with the goal to avoid the disadvantages and enhance the advantages of both.A good P availability in soil was declared to be important for glycosides creation in foxglove (Catizone et al., 1986), and in sage, moderate $\mathrm{P}$ supplies led to significant increment of plant height, number of branches, fresh and dry weights (Naguib, 2011). In this last species, the peak in P demand was observed at the seed formation stage, i.e. later than that detected for nitrogen (Karamanos, 2000).Organic matter is of great significance for providing nutrients to crops, the retention of cations, the complication of toxic elements and micronutrients structural stability infiltration and water maintaining, aeration and microbial activity. Hence, organic matter content constitutes a fundamental component of the productive capacity and stability of soil (Salton et al., 2008). Organic fertilizers provided organic mineral products, including $\mathrm{P}$ and $\mathrm{K}$, through increased soil microbial activity. Changes can happen in the aeration and the water holding capacity of soil in reaction to organic decomposition, (Zárate et al., 2003), favoring the growth and development of plants. Tan (2003) reported that humic material possess two direct and indirect effects on physiological and biochemical processes in plant and on physical, chemical, and biological characteristics of soil. Application of humic acid (HA) has several benefits and agriculturists all over the world are accepting $\mathrm{HA}$ as an integral part of their fertilizer program. This is attributed to the role of nitrogen in nucleic acids and protein synthesis, and phosphorus as an essential component of the energy compounds (ATP and ADP) and phosphoprotein in addition to the role of potassium as an activator of many enzymes (Öpik and Rolfe, 2005).

The interaction between fertilization and irrigation supply proved to be an optimization case for plant growth parameters and yield traits of Roselle. Similar result was observed by Khalil and Yousef (2014) on the same Roselle plant.Most crops have shown significant interactions between nutrients and water, in that water deficiency conditions are often claimed to influence negatively plant's use of nutrients. As a consequence, in the arid and semi-arid areas of the world, more fertilizer is used when water for irrigation is abundant, and under rainfed Mediterranean conditions, fertilizer recommendations are adapted to the average rainfall occurrence (Sivakumar and Huda, 1984).

The anthocyanins are a group of flavonoid derivatives and natural pigments present in the dried flowers of Roselle and their colouralters with pH.Roselle anthocyanin engenders phase II drug-detoxifying enzymes, such as glutathione S-transferase, NAD $(\mathrm{H})$ : quinoneoxi- doreductase, and uridyldiphosphoglucuronosyltransferase in an induced liver damage (CCl4-mediated toxicity) model (Ajiboye et al., 2011).Delphinidin3 -sambubioside is an important anthocyanin molecule drawn out from Roselle calyxes that brings about apoptosis against human leukaemia cells (Hou et al., 2005). The anthocyanin group plays a crucial role in reducing cholesterol. Compost application here enhanced growth and yield of different plant traits and active anthocyanin contents. Elsewhere, research found importance of organic fertilizer application on plant growth and chemical constituents (Khalil and Yousef, 2014 andKhatab, 2016). The anthocyanin percentage was affected by irrigation water quantity where decreasing water quantity increased the anthocyanin percentage of Roselle sepals significantly (Hayat, 2007, Khalil and Abdel-Kader, 2011 and Khalil and Yousef, 2014). Therefore, the shortage of water supply usually led to many disturbances in physiological characters of the plant, such as the reduction in chlorophyll content significantly, indicating the rise in production of plant secondary metabolites like total flavonoids, phenolics and anthocyanins content (Jaafar et al., 2012).

Acknowledgements: support of Central Laboratory of Agriculture Climate and their members who facilitate the work to be conducted

Funding statements: According to the research themes of Agriculture Research Center and Ain Shams University that support the research to be fulfilled

Egypt. J. Hort. Vol. 45, No.1 (2018) 
Conflicts of interest: The work is the property of the authors and was not submitted to any other journals.

\section{References}

Abbas, M.K. and Ali, A.S. (2011) Effect of foliar application of NPK on some growth characters of two cultivars of Roselle (Hibiscus sabdariffa L.). American Journal of Plant Physiology, 6 (4), 220227.

Abou-Arab, A.A., Abu-Salem, F.M. and Abou-Arab, E.A. (2011) Physico-chemical properties of natural pigments (anthocyanin) extracted from Roselle calyces (Hibiscus subdariffa). Journal of American Science, 7 (7), 445-456.

Ajiboye, T.O., Salawu, N.A., Yakubu, M.T., Oladiji, A.T., Akanji, M.A. and Okogun, J.I. (2011) Antioxidant and drug detoxification potentials of Hibiscus sabdariffa anthocyanin extract. Drug and chemical toxicology, 34 (2), 109-115.

Araya, H.T., Soundy, P., Steyn, J.M., Teubes, C., Learmonth, R.A. and Mojela, N. (2006) Response of Herbage Yield, Essential Oil Yield and Composition of South African Rose-Scented Geranium (Pelargonium sp.) to Conventional and Organic Nitrogen.Journal of Essential Oil Research, 18, 111-115.

Babatunde, F.E. and Mofoke, A.L.E. (2006) Performance of Roselle (Hibiscus sabdariffa L) as influenced by irrigation schedules.Pakistan journal of Nutrition, 5 (4), 363-367.

Bavec, F. and Bavec, M. (2006) Organic production and use of alternative crops.CRC Press. New York, USA, $242 \mathrm{p}$.

Begum, H., Medagam, T. R., Rao, N. H., Neelam, S., Pandravada, S.R., and Natarajan, S. (2015) Genetic Diversity and Variability in Landraces for Key Agroeconomic Traits in Vegetable Roselle (Hibiscus Sabdariffa Var. Sabdariffa L.). Jordan Journal of Biological Sciences, 8 (2), 113-125.

Bekeko, Z. (2014) Effect of enriched farmyard manure and inorganic fertilizers on grain yield and harvest index of hybrid maize (bh-140) at Chiro, eastern Ethiopia. African Journal of Agricultural Research, 9 (7), 663-669.

Brinckmann, J.A. (2011) Medicinal plants and extracts - Market news service. Internatinal Trade Centre. Quarterly edition. 69p.

Carrubba, A. (2015) Sustainable Fertilization in Medicinal and Aromatic Plants. Medicinal and Aromatic Plants of the World, Springer Netherlands, pp. 187-203.

Egypt. J. Hort. Vol. 45, No.1 (2018)
Catizone, P. (1986) Coltivazione delle piante medicinali $e$ aromatiche. Pàtronpubl, Bologna, 379 p. (In Italian).

Chiang, C., Soudi, B. and Moreno, A. (1983) Soil nitrogen mineralization and nitrification under Moroccan conditions.Nutrient balances and the need for fertilizers in semi-arid regions. Proceedings of the 17th colloquium of the international Potash institute, Rabat/Marrakesh, Morocco: pp129-139.

Chung, R. S., Chen, C. C. and Ng, L. T. (2010) Nitrogen fertilization affects the growth performance, betaine and polysaccharide concentrations of Lyciumbarbarum.Industrial crops and products, 32 (3), 650-655.

Cobley, L.S. (1976).An introduction to the botany of tropical crops. Longman Group Limited. London, UK, $371 \mathrm{p}$.

Da-Costa-Rocha, I., Bonnlaender, B., Sievers, H., Pischel, I. and Heinrich, M. (2014) Hibiscus sabdariffa L.-A phytochemical and pharmacological review.Food chemistry, 165, 424443.

Du, C.T. and Francis, F.J. (1973) Anthocyanins of roselle (Hibiscus sabdariffa, L.).Journal of Food Science, 38 (5), 810-812.

Duncan, D.B. (1955) Multiple range and multiple F tests.Biometrics, 11(1), 1-42.

Dutt, D., Upadhyay, J.S., Singh, B., and Tyagi, C.H. (2009) Studies on Hibiscus cannabinus and Hibiscus sabdariffa as an alternative pulp blend for softwood: An optimization of kraft delignification process.Industrial Crops and products, 29(1), 1626.

EcoCrop (2007)Hibiscus sabdariffa var. sabdariffa. Food and Agriculture Organization of the UN (FAO) Available online: http://ecocrop.fao.org/ ecocrop/srv/en/crop View?id=6708 (accessed on 01/02/2018).

Eklind, Y., Salomonsson, L., Wivstad, M. and Rämert, B. (1998) Use of herbage compost as horticultural substrate and source of plant nutrients.Biological agriculture \& horticulture, 16 (3), 269-290.

El-Boraie, F.M., Gaber, A.M. and Abdel-Rahman, G. (2009) Optimizing irrigation schedule to maximize water use efficiency of Hibiscus sabdariffa under Shalatien conditions. World Journal of Agricultural Science, 5 (4), 504-14.

El-Naggar, A.A.M., El-Naggar, H. and El-Fawakhry, F.M. (2004) Physiological studies on growth and flowering of Cyprus papyrus, L. 1-Effect of growing media and water requirements.Alex. $J$. Agric. Res, 49 (3), 93-105. 
Hayat, A.E.H. (2007) Physiological studies on Hibiscus sabdariffa L. production in new reclamated soils. M.Sc. thesis, Faculty of Agriculture, Zagazig University 229 p.

Hou, D.X., Tong, X., Terahara, N., Luo, D. and Fujii, M. (2005) Delphinidin 3-sambubioside, a Hibiscus anthocyanin, induces apoptosis in human leukemia cells through reactive oxygen species-mediated mitochondrial pathway. Archives of biochemistry and biophysics, 440 (1), 101-109.

Jaafar, H.Z., Ibrahim, M.H. and MohamadFakri, N.F. (2012) Impact of soil field water capacity on secondary metabolites, phenylalanine ammonialyase (PAL), maliondialdehyde (MDA) and photosynthetic responses of Malaysian Kacip Fatimah (Labisiapumila Benth). Molecules, 17(6), 7305-7322.

Jackson, M.L. (1973) Soil Chemical Analysis. Prentice Hall of India Pvt. Ltd., India.498 p.

Joy, P.P., Thomas, J., Mathew, S. and Skaria, B.P. (1998) Medicinal plants. Kerala Agricultural University, India, $214 \mathrm{p}$.

Karamanos, A.J. (2000) Cultivation of sage. Sage: the genus Salvia. Harwood Academic Publishers, Amsterdam, pp 93-108.

Khalil, A.M., Khalil, S.E. and Ali, T.B. (2012) Effect of water stress, antioxidants and humic acid on Capsicum annuum, L. growth, yield and active ingredient under sandy soil conditions. Egypt. J. of Appl. Sci, 27 (1), 35-56.

Khalil, S. and Yousef, R.M.M. (2014) Study the effect of irrigation water regime and fertilizers on growth, yield and some fruit quality of Hibiscus sabdariffa L.. International Journal of Advanced Research, 2(5), 738-750.

Khalil, S.E. and Abdel-Kader, A.A.S. (2011) The influence of soil moisture stress on growth, water relation and fruit quality of Hibisicussabdariffa L. grown within different soil types.Nature and Science, 9 (4), 62-74.

Khatab, A.Kh. (2016)Response of roselle plants (Hibiscus sabdariffa L.) to pressed olive cake compost types and potassium fertilization rates on newly reclaimed soils at Siwa oasis, Egypt. J. Soil Sci. and Agric. Eng., Mansoura Univ., 7 (5), 365373

Kumar, V., Idem, N.U.A. and Echemwu, C.A. (1986) Yield components of Roselle varieties in Northern Nigeria.East Afr. Agric. J., 51, 108-112.

Lin, T.L., Lin, H.H., Chen, C.C., Lin, M.C., Chou, M.C. and Wang, C.J. (2007) Hibiscus sabdariffa extract reduces serum cholesterol in men and women. Nutrition research, 27 (3), 140-145.
Mahran, G.H., Elhossary, G.A. and Ellabban, H.M. (1978) The effect of nutrient elements on growth and yield of Hibiscus sabdariffa. Planta Medica, 33, 293-294.

Mandour, M.S., Abou-Zied, E.N. and Hassib, M. (1979) Effect of irrigation treatments upon the chemical constituents of Hibiscus sabdariffa L. Plant and Soil, 52 (4), 485-490.

MoeiniAlishah, H., Heidari, R., Hassani, A. and AsadiDizaji, A. (2006) Effect of water stress on some morphological and biochemical characteristics of purple basil (Ocimumbasilicum). J. Biol. Sci., 6 (4), 763-767.

Mohan, R.L. (1989) Conservation and management of the Ganges river dolphin, Platanistagangetica.India. Biology and Conservation of the River Dolphins. Occasional Papers of the IUCN Species Survival Commission, 64-69.

Müller, B.M. and Franz, G. (1992) Chemical structure and biological activity of polysaccharides from Hibiscus sabdariffa. Plantamedica, 58 (1), 60-67.

Naguib, N.Y.M. (2011) Organic vs chemical fertilization of medicinal plants: a concise review of researches. Advances in Environmental Biology, 5 (2), 394-400.

Öpik, H. and Rolfe, S.A. (2005) The Physiology of Flowering Plants. $4^{\text {th }}$ ed. Cambridge University Press, Cambridge, UK, 392 p.

Ottai, M.E.S., Aboud, K.A., Mahmoud, I.M. and ElHariri, D.M. (2006) Stability analysis of roselle cultivars (Hibiscus sabdariffa L.) under different nitrogen fertilizer environments. World Journal of Agricultural Sciences, 2 (3), 333-339.

Oyewole, C.I. and Mera, M. (2010) Response of roselle (Hibiscus sabdariffa L.) to rates of inorganic and farmyard fertilizers in the Sudan savanna ecological zone of Nigeria. African Journal of Agricultural Research, 5 (17), 2305-2309.

Prasad, M., Simmons, P. and Maher, M.J. (2004) Release characteristics of organic fertilizers. InInternational Symposium on Growing Media and Hydroponics, Acta Hort., 644,163-170.

Rutherford, A. (2001) Introducing ANOVA and ANCOVA: a GLM approach. Sage publications Ltd, British library, $181 \mathrm{p}$.

Saha, A.R., Maitra, D.N. Majumdar, B., Saha, S. and Mitra S. (2008) Effect of integrated nutrient management on roselle (Hibiscus sabdariffa) productivity, it mineral nutrition and soil properties. Indian Journal of Agricultural Sciences, 87 (5), 418-21 
Said-Al Ahl, H.A.H. and Abdou, M.A.A. (2009) Impact of water stress and phosphorus fertilizer on fresh herb and essential oil content of dragonhead. Int. Agrophysics, 23, 403-407.

Said-Al Ahl, H.A.H. and Hussein, M.S. (2010) Effect of water stress and potassium humate on the productivity of oregano plant using saline and fresh water irrigation.Ozean Journal of Applied Sciences, 3 (1), 125-141.

Salton, J.C., Mielniczuk, J., Bayer, C., Boeni, M., Conceição, P.C., Fabrício, A.C., Macedo, M.C.M. and Broch, D.L. (2008) Soil aggregation and aggregate stability under crop-pasture systems in MatoGrosso do Sul State, Brazil. Revista Brasileira de Ciência do Solo, 32 (1), 11-21.

Seghatoleslami, M.J., Mousavi, S.G. and Barzgaran, T. (2013) Effect of irrigation and planting date on morphphysiological traits and yield of roselle (Hibiscus sabdariffa). The Journal of Animal and Plant Sciences, 23 (1), 256-260.

Shao, H. B., Chu, L. Y., Jaleel, C. A. and Zhao, C. X. (2008) Water-deficit stress-induced anatomical changes in higher plants.Comptesrendusbiologies, 331(3), 215-225.

Singh, M., GaneshaRao, R. S. and Ramesh, S. (1997) Irrigation and nitrogen requirement of lemongrass [Cymbopogonflexuosus (Steud) Wats] on a red sandy loam soil under semiarid tropical conditions.Journal of essential oil Research, 9 (5), 569-574.

Sivakumar, M.V.K. and Huda, A.K.S. (1983) Potential agricultural productivity in summer and winter rainfall areas. Proceedings of the $17^{\text {th }}$ colloquium of the international Potash institute, Rabat, Marrakech, Morocco, pp 23-48.
StatPoint(2005) The User's Guideto STATGRAPHICS® Centurion $X V$. Stat Point, Inc. Herndon, VA, USA. $287 \mathrm{p}$.

Tan, K. H. (2014) Humic matter in soil and the environment: principles and controversies. CRC Press.Taylor \& Francis Group, NewYork, USA, $465 \mathrm{p}$.

Udoh, J. (2005) Crop Production Techniques for the Tropics Concept Publications Limited, Munshin, Lagos Nigeria.pp 101-106.

WHO (2003) WHO guidelines on good agricultural and collection practices (GACP) for medicinal plants. World Health Organization, Geneva, Swiserland, $72 \mathrm{p}$.

Wilson, F.D. and Menzel, M.Y. (1964) Kenaf (Hibiscus cannabinus), roselle (Hibiscus sabdariffa). Economic Botany, 18 (1), 80-91.

Yang, Y., Watanabe, M., Zhang, X., Zhang, J., Wang, Q. and Hayashi, S. (2006) Optimizing irrigation management for wheat to reduce groundwater depletion in the piedmont region of the Taihang Mountains in the North China Plain. Agricultural Water Management, 82 (1), 25-44.

Zárate, N. A. H., do Carmo Vieira, M. and Bratti, R. (2003) Effects of chicken manure and harvesting date on" TodoAno" green onion yield and gross income. PesquisaAgropecuária Tropical, 33 (2), 73-78.

(Received 14/02/2018, accepted 19/04/2018

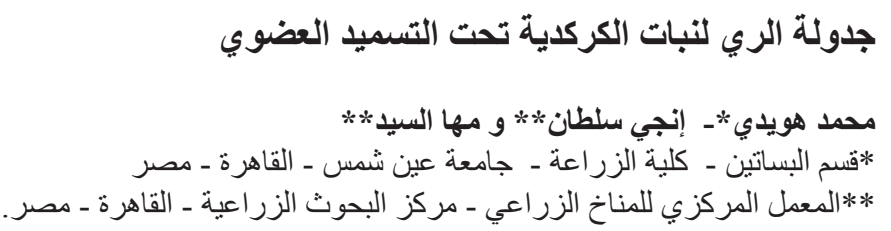

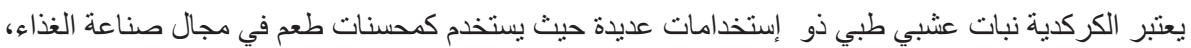

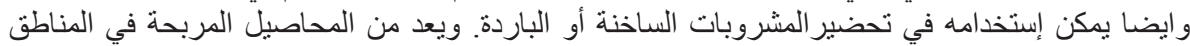

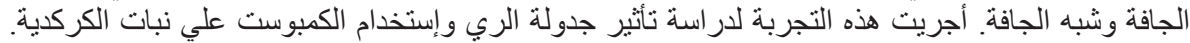

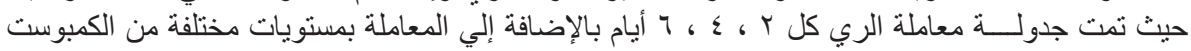

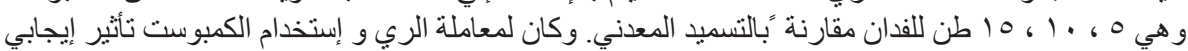

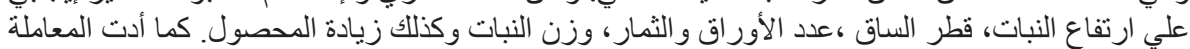

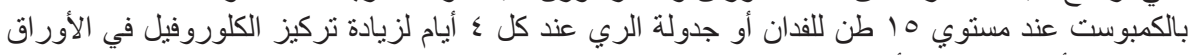

وصبغت الأنثوثيانين في الأزهار.

Egypt. J. Hort. Vol. 45, No.1 (2018) 